\title{
Hydrogen Effect on Local Fracture Emanating from Notches in Pipeline from Steel API X52
}

\author{
J. Capelle, ${ }^{a}$ I. Dmytrakh, ${ }^{\text {b }}$ and G. Pluvinage ${ }^{a}$ \\ ${ }^{a}$ Laboratoire de Fiabilité Mécanique, Ecole Nationale d'Ingénieurs de Metz et Université \\ Paul Verlaine Metz, Metz, France \\ ${ }^{b}$ Karpenko Physico-Mechanical Institute of the National Academy of Sciences of Ukraine, \\ Lvov, Ukraine
}

УДК 539.4

\section{Влияние водорода на локальное разрушение в концентраторах напряжений трубопроводов из стали API X52}

\author{
Ж. Капель ${ }^{a}$, И. Дмитрах ${ }^{\tilde{\sigma}}$ Ж. Плювинаж ${ }^{a}$ \\ а Лаборатория механической надежности, Национальная инженерная школа г. Метц; \\ Университет им. Поля Верлена, Метц, Франция \\ ${ }^{\sigma}$ Физико-механический институт им. Г. В. Карпенко НАН Украины, Львов, Украина
}

Оценена локальная прочность 6 концентраторах напряжений трубопроводной стали АРI X52 в условиях наводораживания при подаче катодного напряжения. Установлень зависилость между кониентрацией водорода и критическим, приводящим к разрушению, уровнем нагружения, а также наличе некоторой критической концентрации водорода, обеспечивающей существенное снижение локального сопротивления материала разрушению.

Ключевые слова: наводораживание металла, концентрация водорода, катодная поляризация, плотность тока, акустическая эмиссия, статическая нагрузка, критическое напряжение, работа локального разрушения.

Introduction. Nowadays, pipelines for gas and oil transportation are integral components of national and global economic infrastructures. There are huge plans for installation of new transcontinental pipelines that require increased attention to their reliable and safe operation. In this frame, the hydrogen degradation of pipeline steels is the important problem among other structural integrity problems.

Specific long-term operation of pipelines promotes of steel hydrogenating process. First of all, pipeline steels encounter hydrogen during transport of sour crude oil and other petroleum products [1]. Moreover, external environmental conditions cause free corroding processes, where hydrogen can appear on metal surface as result of cathodic counterpart of the anodic dissolution reaction. This fact has been proved by several studies [2-4]. Moreover, under service conditions when a cathodic protection system is in place, hydrogen charging of pipeline steels is possible too $[4,5]$. As result, there is the problem of structural integrity of aging buried pipelines having cathodic protection [5]. 
Second reason, which turns one's attention to the problem of hydrogen degradation of pipeline steels, is the fact that hydrogen is supposed to play a decisive role in a future energy system, when fossil fuels become scarce and thus expensive and/or unsuitable from ecological reasons. The number of aspects related to the technical feasibility and economics of developing a hydrogen energy infrastructure are presented and discussed in literature during last decades [6, 7]. The possible use of existing pipeline networks for mixtures of natural gas and hydrogen offers a unique and cost-effective opportunity to initiate the progressive introduction of hydrogen as part of the development of a full hydrogen energy system $[6,8]$.

In the present study, the assessment local strength at notches in pipeline steel API X52 has been done for conditions of cathodic hydrogen charging. The relationship between hydrogen concentration and critical (failure) loading has been found. The existence of some critical hydrogen concentration, which causes the significant loss of local fracture resistance of material, was also shown.

Experimental Procedure. The objects of study were specimens from steel API X52 machined from real pipes of diameter $D=610 \mathrm{~mm}$ and wall thickness $t=11 \mathrm{~mm}$. The specimens were notched for modeling of the longitudinal external defects under operating internal pressure (Fig. 1). The chemical composition of steel and its mechanical properties in air are given in Tables 1 and 2, respectively.

$\mathrm{T}$ a $\mathrm{b} 1 \mathrm{e} 1$

Chemical Composition of Steel (wt.\%)

\begin{tabular}{|c|c|c|c|c|c|c|c|c|c|c|c|}
\hline $\mathrm{C}$ & $\mathrm{Mn}$ & $\mathrm{Si}$ & $\mathrm{P}$ & $\mathrm{S}$ & $\mathrm{Al}$ & $\mathrm{Nb}$ & $\mathrm{Cu}$ & $\mathrm{Cr}$ & $\mathrm{Ni}$ & $\mathrm{V}$ & $\mathrm{Ti}$ \\
\hline 0.08 & 1.06 & 0.26 & 0.019 & 0.003 & 0.039 & 0.041 & 0.018 & 0.02 & 0.019 & 0.054 & 0.003 \\
\hline
\end{tabular}

T a b 1 e 2

Mechanical Properties of Steel in Air

\begin{tabular}{|c|c|c|}
\hline$\sigma_{u}, \mathrm{MPa}$ & $\sigma_{Y}, \mathrm{MPa}$ & Elongation, \% \\
\hline 528 & 410 & 30.2 \\
\hline
\end{tabular}

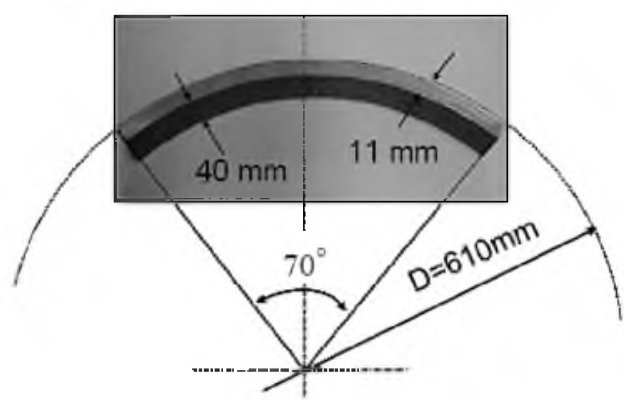

Fig. 1. "Roman tile" specimen.

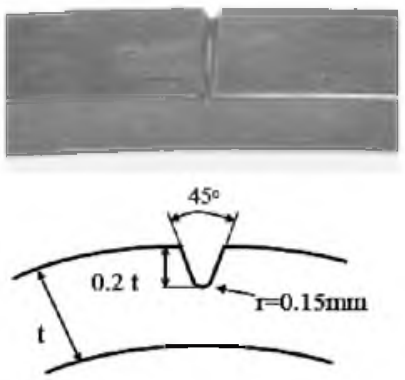

Fig. 2. Notch geometry.

For fracture toughness test the special "Roman tile" [9] specimens were used (Fig. 1). The specimens were notched for modeling of the longitudinal external defects under operating internal pressure (Fig. 2). 
$\mathrm{T}$ a b 1 e 3

Chemical Composition of NS4 Solution (g/l) [10]

\begin{tabular}{|c|c|c|c|}
\hline $\mathrm{NaHCO}_{3}$ & $\mathrm{KCl}$ & $\mathrm{CaCl}_{2}$ & $\mathrm{MgCl}_{2} \cdot \mathrm{H}_{2} \mathrm{O}$ \\
\hline 0.483 & 0.120 & 0.137 & 0.131 \\
\hline
\end{tabular}

The study was conducted in special soil solution NS4 with $p H=6.7$ [10]. Chemical composition of this environment is given in Table 3. In these conditions i.e., in deoxygenated, near-neutral $\mathrm{pH}$ solution, hydrogen atoms are generated on the steel surface by the electrochemical reduction of water molecules $[2,3]$ :

$$
\mathrm{H}_{2} \mathrm{O}+e \rightarrow \mathrm{H}_{a d s}+\mathrm{OH}^{-}
$$

The adsorbed hydrogen atoms can subsequently combined to $\mathrm{H}_{2}$ molecules by the chemical reaction:

$$
2 \mathrm{H}_{\text {ads }} \rightarrow \mathrm{H}_{2}
$$

or the electrochemical reaction:

$$
\mathrm{H}_{a d s}+\mathrm{H}_{2} \mathrm{O}+e \rightarrow \mathrm{H}_{2}+\mathrm{OH}^{-} \text {, }
$$

or can be absorbed by the steel:

$$
\mathrm{H}_{a d s} \rightarrow \mathrm{H}_{a b s} .
$$

Noteworthy is that, according to $[2,3]$, the absorbed hydrogen atom concentration under the cathodic polarisation depends on the hydrogen atom recombination mechanisms. When the chemical reaction (2) dominates the hydrogen atom recombination, the applied cathodic polarisation enhances the generation of hydrogen atoms and thus the amount of hydrogen atoms penetrating into the steel. The absorbed hydrogen atom concentration will increase continuously with the cathodic polarisation potential. In the case of electrochemical reaction (3) dominating the hydrogen atom recombination, the cathodic polarisation promotes the generation of hydrogen atoms through reaction (1), and simultaneously, enhances the hydrogen atom recombination through reaction (3). Thus, the role of cathodic polarisation is to generate hydrogen atoms and also to recombine hydrogen atoms.

However, the prevailing number of reported studies [11-14] were conducted with using of cathodic charging of hydrogen under high density of polarisation current. Such charging is not truly representative of the hydrogen entry conditions in real operating pipelines, where there is the situation of freely corroding system [15]. This fact was pointed out in work [4].

Accounting for the fact that a steady state condition of hydrogen charging cannot be imposed nor obtained in a freely corroding situation, in this study the following procedure has been used. The specimens were hydrogen charged at some constant potential of polarization $E_{p}=$ const, which is slightly negative than free corrosion potential for given steel: $E_{\text {cath }}=-1000 \mathrm{mV}(\mathrm{SCE})$ and $E_{\text {corr }}=-800 \mathrm{mV}$ (SCE). For this experimental procedure the Potentiostat VMP [16] has been used. 
The specimens were immersed into the cell with special NS4 solution and exposed under constant potential of polarization $E_{c a t h}=$ const. The surface of auxiliary electrode was parallel to notch plane with some constant distance $h$. The mutual location of working (specimen) and auxiliary electrodes is given in Fig. 3.

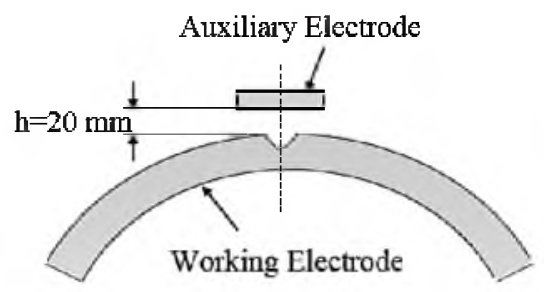

Fig. 3. Mutual location of working electrode (specimen) and auxiliary electrode.

During the hydrogen-charging process, the specimens were loaded. The level of load was defined as gross hoop stress $\sigma_{\text {gross }}$, which corresponds of the internal pressure in pipe under operation $p_{\text {exp }}=70$ bar.

The hydrogen-charging process was controlled by registration of the cathodic polarisation current $I_{\text {cath }}(\tau)$. The total quantity of evaluated hydrogen on metal surface during time of exposition $\tau_{\text {exp }}$ can be assessed as

$$
Q_{H}^{e v}=\int_{0}^{\tau_{\exp }} I_{c a t h}(\tau) d \tau \quad \text { under } \quad E_{\text {cath }}=\text { const. }
$$

Hydrogen concentration in metal has been determined on the base of hydrogen discharging process under anodic polarisation with using of hydrogen electrochemical oxidation method proposed in work [17]. Hear the standard threeelectrode electrochemical cell has been used. The hydrogen discharging of specimens were curried out in $0.2 \mathrm{M} \mathrm{NaOH}(\mathrm{pH}=12.4)$ solution under anodic polarisation $E_{\text {anodic }}=168 \mathrm{mV}$ (SCE) during some defined time $\tau_{\text {dis }}$ (see Fig. 4). The total quantity of absorbed hydrogen by metal can be defined as

$$
Q_{H}^{a b s}=\int_{0}^{\tau_{d i s}}\left[I_{H}(\tau)-I_{r e f}(\tau)\right] d \tau \quad \text { under } \quad E_{\text {anodic }}=\text { const }
$$

where $I_{H}(\tau)$ is anodic polarization current for hydrogen charged specimen and $I_{\text {ref }}(\tau)$ is anodic polarisation current for specimen without hydrogen (reference curve). Calculation of hydrogen concentration was done according to formula:

$$
C_{H}=\frac{Q_{H}^{a b s}}{z F v}
$$

Here $z$ is the number of electrons take in reaction, $F$ is the Faraday constant, and $v$ is the effective volume of specimen: $C_{H}\left[\mathrm{~mol} / \mathrm{cm}^{3}\right], Q_{H}^{a b s}[\mathrm{~A} \cdot \mathrm{s}], z=1, F=$ $=9.65 \cdot 10^{4} \mathrm{C} / \mathrm{mol}$, and $v=0.256 \mathrm{~cm}^{3}$. 


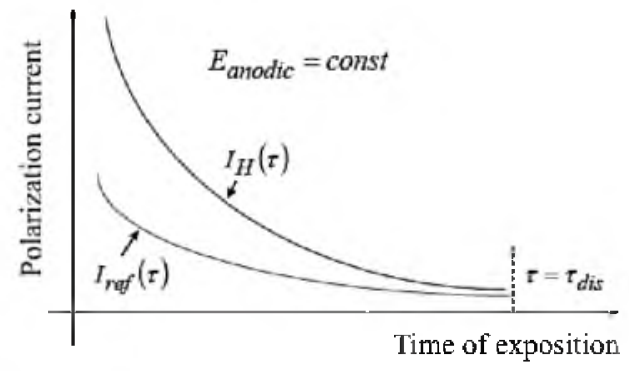

Fig. 4. Schematic view of hydrogen discharging process under anodic polarization.

After assigned exposition under hydrogenating conditions, all specimens were tested to failure under increasing static loading, according to three-point bending scheme. Testing machine Instron was used under the constant rate of displacement of grips $d \Delta / d \tau=0.02 \mathrm{~mm} / \mathrm{s}$.

The load-displacement diagram and acoustic emission (AE) signals were simultaneously registered by PC during the tests. The start of fracture process has been defined by acoustic emission method [18]. The general scheme of tests is given in Fig. 5.

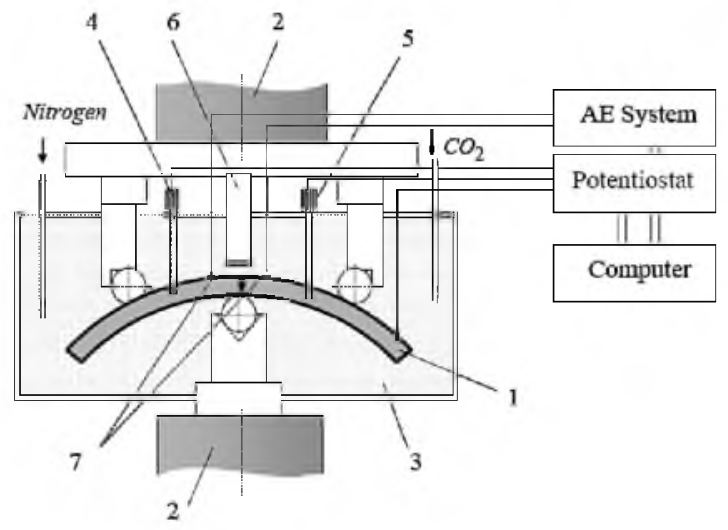

Fig. 5. Schematic view of testing equipment for fracture toughness determining of hydrogen charged specimens: (1) "Roman tile" specimen, (2) loading device of testing machine, (3) corrosion cell with NS4 solution, (4) $\mathrm{pH}$ electrode, (5) reference calomel electrode, (6) auxiliary electrode, and (7) acoustic emission sensors.

Results and Discussion. Process of hydrogen charging of pipeline steels at the given conditions of cathodic polarisation was characterised by following parameters: hydrogen concentration in metal $C_{H}$, total quantity of evaluated $Q_{e v}$ and absorbed $Q_{a b s}$ hydrogen; averaged meaning of cathodic current density $i_{c}$ and coefficient of efficiency of hydrogen permeation in metal $k=Q_{a b s} / Q_{e v}$. The numerical values of these parameters are given in Table 4, respectively for unloaded and stressed metal.

Comparative assessment of hydrogen generation process on metal surface and hydrogen permeation in metal for unloaded and stressed specimens showed on intensifying of both processes by applied stress (gross stress $\sigma_{\text {gross }}$ which corresponds of the internal pressure in pipe under operation $p_{\exp }=70$ bar). 
Moreover, it can be concluded that the efficiency of hydrogen absorption in metal is quite low and depends on time of exposition. Under $\tau \geq 20 \mathrm{~h}$ there is the tendency of monotonic decreasing of parameter $k$ up to level $k=0.0013-0.0031$ (Fig. 6a). Generally, applied stress increases the concentration in metal (Fig. 6b). At that, under $\tau \geq 100 \mathrm{~h}$ the difference between hydrogen concentration in unloaded and stressed metal can exceed more than five times.

$\mathrm{T}$ a b 1 e 4

Data for Determining of Hydrogen Concentration in Pipeline Steel API X52

\begin{tabular}{|c|c|c|c|c|c|}
\hline \multirow[t]{2}{*}{$\tau, \mathrm{h}$} & \multirow{2}{*}{$\begin{array}{c}Q_{H}^{e v} \\
\mathrm{~mA} \cdot \mathrm{s}\end{array}$} & \multirow{2}{*}{$\begin{array}{c}i_{c} \\
\mathrm{~mA} / \mathrm{cm}^{2}\end{array}$} & \multicolumn{2}{|c|}{$\tau_{\text {dis }}=1 \mathrm{~h}$} & \multirow[t]{2}{*}{$k$} \\
\hline & & & $Q_{H}^{a b s}, \mathrm{~mA} \cdot \mathrm{s}$ & $C_{H}, 10^{6} \mathrm{~mol} / \mathrm{cm}^{3}$ & \\
\hline \multicolumn{6}{|c|}{ Unloaded metal } \\
\hline 1 & 297.59 & 0.1290 & 4.18 & 0.169 & 0.0140 \\
\hline 3 & 636.23 & 0.0920 & 9.85 & 0.399 & 0.0155 \\
\hline 15 & 989.55 & 0.0290 & 18.43 & 0.746 & 0.0186 \\
\hline 66 & 5148.3 & 0.0380 & 22.11 & 0.895 & 0.0043 \\
\hline 148 & 5371.3 & 0.0157 & 15.51 & 0.628 & 0.0029 \\
\hline 168 & 12443.3 & 0.0364 & 16.75 & 0.678 & 0.0013 \\
\hline \multicolumn{6}{|c|}{ Stressed metal } \\
\hline 46 & 57,360 & 0.226 & 362.4 & 2.224 & 0.0063 \\
\hline 101 & 168,798 & 0.240 & 1216.5 & 5.924 & 0.0072 \\
\hline 118 & 147,522 & 0.524 & 458.6 & 2.814 & 0.0031 \\
\hline 167.3 & 178,564 & 0.463 & - & - & - \\
\hline
\end{tabular}
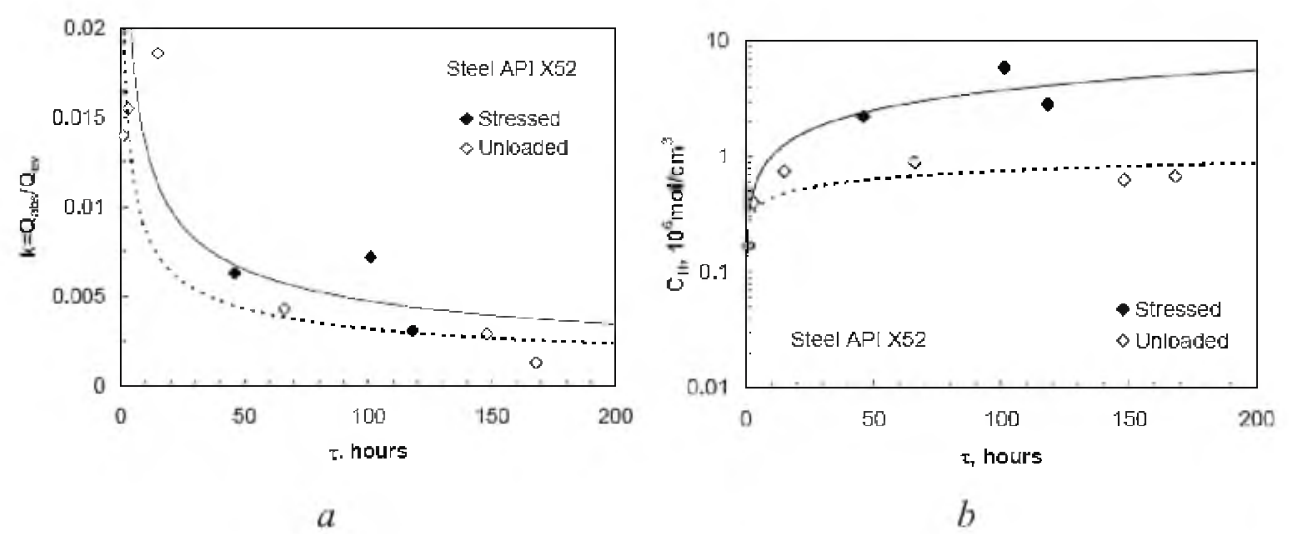

Fig. 6. Influence of applied stress on efficiency of hydrogen permeation in metal $(a)$ and hydrogen concentration $(b)$ in steel API X52.

Based on the experimental results, the increasing of hydrogen concentration in metal versus time of exposition of specimens in the hydrogenating conditions can be described by power relation: 


$$
C_{H}=A \tau^{m} \cdot 10^{-6} \quad\left[\mathrm{~mol} / \mathrm{cm}^{3}\right]
$$

where $A$ and $m$ are constants (Table 5).

$\mathrm{T}$ a b 1 e 5

Meanings of Constants in (8)

\begin{tabular}{|c|c|c|}
\hline Test conditions & $A$ & $m$ \\
\hline Unloaded metal & 0.253 & 0.24 \\
\hline Stressed metal & 0.300 & 0.57 \\
\hline
\end{tabular}

The results of fracture toughness study of notched specimens in presence of hydrogen are given as dependencies of total work of local fracture $W_{f(t a t a l)}$ emanating from notch or its plastic component $W_{f \text { (plastic) }}$ versus time of exposition $\tau$ of specimens under hydrogenating conditions. The scheme of determination of parameters $W_{f(t a t a l)}$ and $W_{f(\text { plastic })}$ is presented in Fig. 7. The dependencies of parameters $W_{f(t o t a l)}$ and $W_{f(\text { plastic })}$ on the hydrogen concentration $C_{H}$ in metal were also obtained with using of analytical relation (8). The received data are given in diagrams (Fig. 8) and in Table 6.

$\mathrm{T}$ a b 1 e 6

Data of Fracture Toughness Tests of Notched "Roman Tile" Specimens in Presence of Hydrogen

\begin{tabular}{|c|c|c|c|c|c|}
\hline \multirow{2}{*}{$\tau, \mathrm{h}$} & $\begin{array}{c}W_{f(\text { total })} \\
\mathrm{N} \cdot \mathrm{m}\end{array}$ & $\begin{array}{c}W_{f(\text { plastic })} \\
\mathrm{N} \cdot \mathrm{m}\end{array}$ & $\begin{array}{c}W_{f(\text { elastic })} \\
\mathrm{N} \cdot \mathrm{m}\end{array}$ & \multicolumn{2}{|c|}{$C_{H}, 10^{6} \mathrm{~mol}^{\mathrm{cm}}{ }^{3}$} \\
\cline { 5 - 6 } & 32.12 & 19.22 & 12.91 & 2.224 & 2.660 \\
\hline 46 & 26.57 & 15.44 & 11.12 & 5.924 & 4.165 \\
\hline 101 & 15.53 & 4.68 & 10.85 & 2.814 & 4.551 \\
\hline 118 & 10.47 & 3.90 & 6.57 & - & 5.553 \\
\hline
\end{tabular}

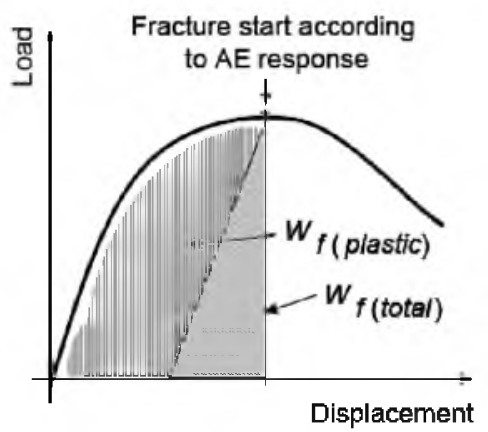

Fig. 7. Scheme of local fracture work determination. 


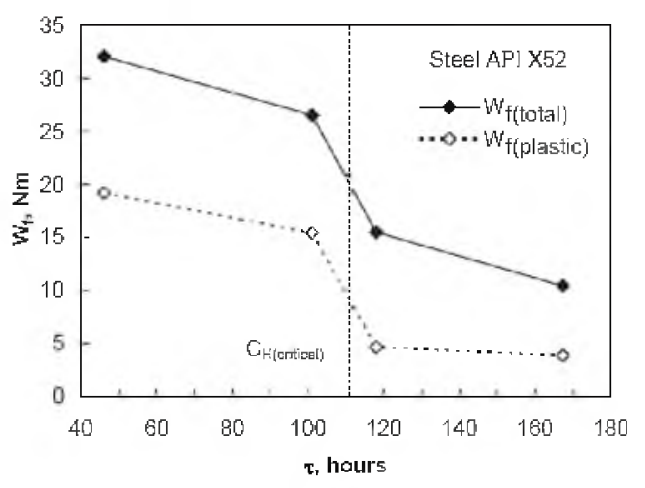

$a$

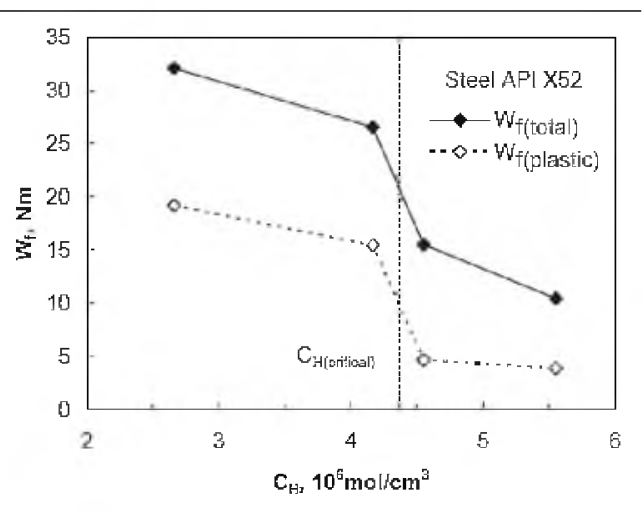

$b$

Fig. 8. Work of local fracture emanating from notch in steel API X52 as function of time of exposition of specimens in hydrogenating conditions $(a)$ and as function of hydrogen concentration in metal $(b)$.

The main observation to be made from these results is existence of some critical time of exposition and as consequence - some critical hydrogen concentration $C_{H \text { (critical) }}$, when the essential decreasing of fracture toughness value is observed. Therefore, a concentration of hydrogen in metal defines its local fracture resistance. From this reason the diagram "work of local fracture hydrogen concentration" can be considered as an invariant curve for a given system "material-environment." For steel X52 the value of critical hydrogen concentration is about $C_{H} \geq 4.3 \cdot 10^{-6} \mathrm{~mol} / \mathrm{cm}^{3}$ (Fig. 8a). This value may be considered as one of important engineering parameter for reliability assessment of exploited pipelines.

Noteworthy is that definition "critical concentration" is often used in studies of problems of hydrogen in metals and alloys [7, 19-21]. Although in different works this term has different physical sense. For example, according to work [19], hydrogen treatment below the "critical" content was found to cause the substantial rearrangement of dislocations and de-cohesion of grain boundaries and in overcritical condition, the formation of micro crevices at the grain and phase boundaries has been occurred. Others authors use this definition under developing of local fracture criteria $[7,20]$.

Here, two characteristic value of hydrogen concentration in metal of pipe may be classified. The first one is concentration $C_{H(0)}$, strating from which hydrogen affects on local strength of material. The second one is critical concentration $C_{H \text { (critical) }}$, which causes the significant loss of local fracture resistance of material. The general tendency of hydrogen effect on local strength of pipeline steel at notches is given in Fig. 9.

Our study is limited by a case of fracture toughness of notched specimens which model the mechanical defects like scratches or dents. It is clear that for deeper understanding of hydrogen contribution in durability of pipelines under real operating conditions, the corrosion and corrosion fatigue studies are required. The hydrogen may affect on early stages of fatigue damage accumulation on the surface [22], especially when there is a gradient of hydrogen concentration at near-surface 
layer and bulk of material [23]. The problem of fatigue crack propagation accelerated by hydrogen is also important, because sometimes the pipeline leak occurs as result of subcritical crack growth [24].

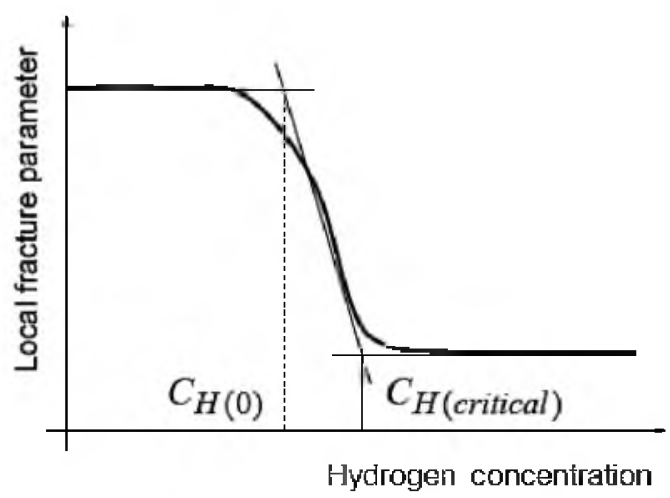

Fig. 9. General tendency of hydrogen effect on local strength of pipeline steels at notches.

Finally, it may be noted that data obtained can be considered as basis for further calculation with the aim of fracture risk assessment of defected pipelines. This may be done according to modified SINTAP procedure for case of notch, proposed in work [25], and where notch-based failure assessment diagrams (NFAD) are developed.

Conclusions. The study of hydrogen-charging process of API grade pipeline steels X52 was conducted and its local strength at notches in presence of hydrogen was determined. The results obtained yield the following conclusions. The given steel demonstrates the sensitivity to hydrogenating in deoxygenated, near- neutral $p H$ NS4 solution under "soft" cathodic polarisation at $E_{\text {cath }}=-1000 \mathrm{mV}$ (SCE) The efficiency of hydrogen permeation in metal is quite low and depends on time of exposition. It can be stated that under $\tau \geq 20 \mathrm{~h}$ there is the tendency of monotonic decreasing of parameter $k$ up to level $k=0.0013-0.0031$.

The applied stress, which equivalent to gross hoop stress in pipe wall under operating internal pressure 70 bars, significantly accelerates hydrogen charging of steel. The difference between hydrogen concentration in unloaded and stressed metal can exceed more than five times.

For steel X52 some critical hydrogen concentration exists $\left(C_{H} \geq 4.3 \cdot 10^{-6}\right.$ $\mathrm{mol} / \mathrm{cm}^{3}$ ), which causes the significant loss of local fracture resistance of material. This value might be considered as one of important engineering parameter for reliability assessment of exploited pipelines.

For assessment of local strength at notches in presence of hydrogen the diagram "work of local fracture - hydrogen concentration" is effective and it can be considered as an invariant curve for a given system "material-environment."

Acknowledgments. Presented study was partly performed within the framework of NATYRALHY project (Contract No. SES6/2004/502661). I. Dmytrakh would like to thank Ecole Nationale d'Ingénieurs de Metz (ENIM) and Université Paul Verlaine Metz for the opportunity to conduct this research. 


\section{Резиме}

Оцінено локальну міцність у концентраторах напружень трубопровідної сталі API X52 в умовах наводорожування при подачі катодного напруження. Установлено залежність між концентрацією водню і критичним рівнем навантаження, який призводить до руйнування, а також присутність деякої критичної конщентрації водню, що забезпечує суттєве зниження локального опору матеріалу руйнуванню.

1. C. Azevedo, "Failure analysis of a crude oil pipeline," Eng. Failure Anal., 14, 978-994 (2007).

2. Y. F. Cheng and L. Niu, "Mechanism for hydrogen evolution reaction on pipeline steel in near-neutral pH solution," Electrochemistry Comm., 9, 558562 (2007).

3. Y. F. Cheng, "Fundamentals of hydrogen evolution reaction and its implications on near-neutral pH stress corrosion cracking of pipelines," Electrochimica Acta, 52, 2661-2667 (2007).

4. S. Dey, A. K. Mandhyan, S. K. Sondhi, and I. Chattoraj, "Hydrogen entry into pipeline steel under freely corroding conditions in two corroding media," Corrosion Science, 48, 2676-2688 (2006).

5. S. A. Shipilov and I. L. May, "Structural integrity of aging buried pipelines having cathodic protection," Eng. Failure Anal., 13, 1159-1176 (2006).

6. Y. Yürüm (Ed.), Hydrogen Energy Systems: Production and Utilisation of Hydrogen and Future Aspects, Kluwer Academic Publisher, Dordrecht, Boston, London (1995).

7. J. W. Hanneken, "Hydrogen in metals and other materials: a comprehensive reference to books, bibliographies, workshops, and conferences," Int. J Hydrogen Energy, 24, No. 10, 1005-1026 (1999).

8. B. Ibeh, C. Gardner, and M. Ternan, "Separation of hydrogen from a hydrogen/methane mixture using a PEM fuel cell," Int. J. Hydrogen Energy, 32, 908-914 (2007).

9. H. Adib-Ramezani, J. Jeong, and G. Pluvinage, "Structural integrity evaluation of X52 gas pipes subjected to external corrosion defects using the SINTAP procedure," Int. J. Press. Vess. Piping, 83, 420-432 (2006).

10. S. X. Mao and M. Li, "Mechanics and thermodynamics on the stress and hydrogen interaction in crack tip stress corrosion: experiment and theory," $J$. Mech. Phys. Solids, 46, No. 6, 1125-1137 (1998).

11. D. Hardie, E. A. Charles, and A. H. Lopez, "Hydrogen embrittlement of high strength pipeline steels," Corrosion Science, 48, 4378-4385 (2006).

12. A. Torres-Islas, V. M. Salinas-Bravo, J. L. Albarran, J. G. Gonzalez-Rodriguez, "Effect of hydrogen on the mechanical properties of $\mathrm{X}-70$ pipeline steel in diluted $\mathrm{NaHCO}_{3}$ solutions at different heat treatments," Int. J. Hydrogen Energy, 30, 1317-1322 (2005). 
13. T. Zhang, W. Y. Chu, K. W. Gao, and L. J. Qiao, "Study of correlation between hydrogen-induced stress and hydrogen embrittlement," Mater. Sci. Eng., A347, 291-299 (2003).

14. Y. F. Cheng, "Analysis of electrochemical hydrogen permeation through X-65 pipeline steel and its implications on pipeline stress corrosion cracking," Int. J. Hydrogen Energy, 32, 1269-1276 (2007).

15. M. C. Li and Y. F. Cheng, "Mechanistic investigation of hydrogen-enhanced anodic dissolution of X-70 pipe steel and its implication on near-neutral $\mathrm{pH}$ SCC of pipelines," Electrochimica Acta, 52, 8111-8117 (2007).

16. Potentiostat VMP. Manual, Priceton Applied Research (2004).

17. M. Yan and Y. Weng, "Study on hydrogen absorption of pipeline steel under cathodic charging," Corrosion Science, 48, 432-444 (2006).

18. Vallen-Systeme Acoustic Emission. Manual, Vallen-Systeme GmbH, Germany (2006).

19. E. Lunarska E., Y. Ososkov, and Y. Jagodzinsky, "Correlation between critical hydrogen concentration and hydrogen damage of pipeline steel," Int. J. Hydrogen Energy, 22, No. 2/3, 279-284 (1997).

20. J. Lufrano and P. Sofronis, "Enhanced hydrogen concentrations ahead of rounded notches and cracks - competition between plastic strain and hydrostatic stress," Acta Metal., 46, No. 5, 1519-1526 (1998).

21. V. Venegas, F. Caleyo, J. L. Gonzalez, et al., "EBSD study of hydrogeninduced cracking in API-5L-X46 pipeline steel," Scripta Mater., 52, 147-152 (2005).

22. R. Akid, I. M. Dmytrakh, and J. Gonzalez-Sanchez, "Fatigue damage accumulation: the role of corrosion on the early stages of crack growth," Corrosion Eng., Sci., Technol., 41, No. 4, 328-335 (2006).

23. V. Olden, C. Thaulow, R. Johnsen, and E. Ostby, "Cohesive zone modelling of hydrogen-induced stress cracking in $25 \% \mathrm{Cr}$ duplex stainless steel," Scripta Mater., 57, 615-618 (2007).

24. I. Dmytrakh, "Corrosion fatigue cracking and failure risk assessment of pipelines," in: G. Pluvinage and M. H. Elwany (Eds.), NATO Science for Peace and Security Series "Safety, Reliability, and Risks Assessments with Water, Oil, and Gas Pipelines," Springer (2008), pp. 99-113.

25. G. Pluvinage, "General approaches of pipeline defect assessment," in: G. Pluvinage and M. H. Elwany (Eds.), NATO Science for Peace and Security Series "Safety, Reliability, and Risks Assessments with Water, Oil, and Gas Pipelines," Springer (2008), pp. 1-22. 